\title{
Evaluation of advanced selections of strawberry in southern Brazil
}

\section{Avaliação de seleções avançadas de morangueiro no Sul do Brasil}

\author{
Daniel Suek ZANIN'; Antonio Felippe FAGHERAZZI ${ }^{2}$; Katiana Vanusa TILLWITZ ${ }^{3}$ \\ Juliana Martins de LIMA ${ }^{4}$; Aike Anneliese KRETZSCHMAR
}

\begin{abstract}
${ }^{1}$ Autor para correspondência - Eng. Agrônomo, doutorando em Produção Vegetal - Universidade do Estado de Santa Catarina, Centro de Ciências Agroveterinárias, Departamento de Agronomia - Av. Luís de Camões, 2090, Conta Dinheiro, 88520-000, Lages, SC, e-mail: dsuekzanin@gmail.com

2 Prof. Colaborador - Universidade do Estado de Santa Catarina, Centro de Ciências Agroveterinárias, Departamento de Agronomia, e-mail: antonio.fagherazzi@gmail.com

${ }^{3}$ Acadêmica de Agronomia - Universidade do Estado de Santa Catarina, Centro de Ciências Agroveterinárias, Departamento de Agronomia, e-mail: katianatillwitz@gmail.com

${ }^{4}$ Eng. Agrônoma, mestranda em Produção Vegetal - Universidade do Estado de Santa Catarina, Centro de Ciências Agroveterinárias, Departamento de Agronomia, e-mail: juumartinsslima@gmail.com

${ }^{5}$ Prof. Titular - Universidade do Estado de Santa Catarina, Centro de Ciências Agroveterinárias, Departamento de Agronomia, e-mail: aikeanneliese@yahoo.com.br
\end{abstract}

Recebido em: 12-04-2019; Aceito em: 01-08-2019

\begin{abstract}
Strawberry cultivation is technically considered a complex activity, which demands high inputs in investment and manpower. One of the most relevant technical aspects of this crop is the choice of correct cultivars. A highly feasible way to obtain fully adapted genotypes with high production potential and fruit quality is to select the genotypes with best performance in the producing region itself. The objective of this work was to evaluate the advanced selections of strawberry on productive performance, fruit quality and resistance to strawberry leaf spot, powdery mildew and anthracnose, under conditions of the municipality of Lages, Santa Catarina State. Eleven genotypes were evaluated, being one commercial cultivar - San Andreas - and ten advanced selections, namely: ITA 12,103-15; ITA 12,103-12; ITA 12,103-22; ITA 10,107-6; ITA 10,107-7; ITA 13,097-05; ITA 10,133-2; ITA 10,128-9; ITA 12,103-6 and ITA 10,107-12. The experimental design was in randomized blocks, with three replications, and plots constituted by eleven plants. The cultivar San Andreas presented the best results for total ( $\left.657.06 \mathrm{~g} \mathrm{plant}^{-1}\right)$ and commercial production (547.77 $\left.\mathrm{g} \mathrm{plant}^{-1}\right)$, and number of commercial fruits per plant (30.81 fruits plant $\left.{ }^{-1}\right)$. The selections ITA 10,128-9; ITA 10,133-2; ITA 13,097-5; ITA 10,107-7 and ITA 10,107-12 obtained the highest values for soluble solids content, above to $8.5^{\circ}$ Brix, being superior than San Andreas cultivar for this variable. The genotypes ITA 12,103-15 and ITA 10,107-12, on the other hand, were the most resistant to the diseases evaluated.
\end{abstract}

Additional keywords: Fragaria x ananassa Duch.; fruit quality; pest resistance; plant breeding; small fruits; yield.

\section{Resumo}

O cultivo de morangueiro é uma atividade complexa do ponto de vista técnico e demanda elevado investimento em insumos e mão-de-obra. Um dos aspectos técnicos mais relevantes para a cultura é a escolha correta das cultivares. Uma maneira altamente viável de se obter genótipos plenamente adaptados e com elevado potencial de produção e qualidade de frutos é a realização de um programa de melhoramento genético na própria região produtora. $\mathrm{O}$ objetivo deste trabalho foi avaliar seleções avançadas de morangueiro quanto ao desempenho produtivo, qualidade de frutos e resistência à mancha-de-micosferela, oídio e antracnose, nas condições do município de Lages, em Santa Catarina. Foram confrontados onze genótipos, sendo uma cultivar comercial San Andreas - e dez seleções avançadas, a saber: ITA 12,103-15; ITA 12,103-12; ITA 12,103-22; ITA 10,107-6; ITA 10,107-7; ITA 13,097-05; ITA 10,133-2; ITA 10,128-9; ITA 12,103-6 e ITA 10,107-12. Foi utilizado o delineamento experimental em blocos casualizados, com três repetições, e parcelas constituídas por onze plantas. A cultivar San Andreas apresentou os melhores resultados para produção total $\left(657,06 \mathrm{~g}\right.$ planta- $\left.^{-1}\right)$ e comercial (547,77 $\left.\mathrm{g} \mathrm{planta}^{-1}\right)$, e número de frutos comerciais por planta (30,81 frutos planta $\left.{ }^{-1}\right)$. As seleções ITA 10,128-9; ITA 10,133-2; ITA 13,097-5; ITA 10,107-7 e ITA 10,107-12 obtiveram os valores mais elevados para teor de sólidos solúveis, com resultados acima de $8,5^{\circ}$ Brix, sendo superiores à cultivar San Andreas para esta variável. Os genótipos ITA 12,103-15 e ITA 10,107-12, por sua vez, foram os mais resistentes às doenças avaliadas.

Palavras-chave adicionais: Fragaria $\mathrm{x}$ ananassa Duch.; melhoramento genético; produtividade; qualidade de frutos; resistência a doenças. 


\section{Introduction}

Strawberry (Fragaria $\mathrm{x}$ ananassa Duch.) is an agricultural species belonging to the group of small fruits, with increasing socioeconomic importance at Brazilian level (Fagherazzi et al., 2017b). Typical crop of small areas, often less than 1 hectare, this agricultural species demands high investment in infrastructure, inputs and labor (Ronque et al, 2013).

The choice of the best cultivar, or cultivars, plays a key role in all aspects of the production chain, such as planting season, fertilization, spacing adequacy, phytosanitary control, post-harvest conservation period, and the destination of the product in the market. The selection of the incorrect cultivar could compromise the crop viability, even though all other management aspects are performed in the best possible way (Antunes et al., 2010).

The environmental factors that control flowering and fruiting of strawberry are temperature, photoperiod, and the interaction between them (Heide et al. 2013). In addition, the thermal sum exerts influence on the vegetative development and the entry into the productive phase (Tazzo et al., 2015). Thus, a genotype developed and tested at one site may behave adversely in another region (Costa et al., 2015; 2016; Mathey et al., 2017).

In the second half of the 20th century, Brazilian strawberry cultivars were developed in two institutions: the Agronomic Institute of Campinas (IAC), and Embrapa Clima Temperado, in Pelotas-RS. These programs, however, have suffered interruptions, and in recent years they have not released new cultivars (Antunes \& Peres, 2013). The dependency of the imported cultivars, besides being an obstacle to improve yield and fruit quality, increases the production costs, since the producers indirectly pay royalties to the companies that have the right to commercialize these cultivars (Galvão, 2014).

Most of the strawberry cultivars currently used in Brazil were developed at the United States, at the breeding programs of the universities of California and Florida, and at Spain. In Brazilian territory, these cultivars do not always express the maximum potential for yield and fruit flavor, and are often highly susceptible to phytosanitary problems (Fagherazzi et al., 2017a).

Under Brazilian conditions, foreign cultivars tend to have good yield potential and high fruit size (Fagherazzi et al., 2017b). For example, there are the North-American cultivars San Andreas, Albion, Camarosa, Aromas, Oso Grande, Strawberry Festival, and Portola, cultivated by many producers (Fagherazzi, 2017). Although these cultivars generally have attractive color and good pulp firmness, excessively acidic taste for the Brazilian market has been a common problem (Oliveira \& Bonow, 2012). According to the same authors, there is also a lack of cultivars resistant to the main diseases for this crop at national level, such as strawberry leaf spot (Mycosphaerella fragariae), anthracnose (Colletotrichum acutatum) and powdery mildew (Sphaerotteca fuliginea).
The greatest chance of a given genotype to express the maximum of its genetic potential is in the region where it was selected (Mathey et al., 2017). Thus, the implementation of a breeding program aimed at the production places can be one of the most effective ways to obtain fully adapted cultivars with the maximum productive and qualitative potential, reducing the dependence on imported cultivars (Galvão, 2014).

As strawberry genotypes show high interaction with environment, a great part of the most important commercial characteristics is quantitative, controlled by several genes, and subjected to environmental influence (Mishra et al., 2015). In order to obtain genotypes with desired characteristics, hundreds of hybridizations are carried out, followed by selection of the best genotypes within the progenies obtained (Galvão, 2014). This selection, in turn, is a complex work, since only a small part of the genotypes obtained in the crosses has the combination of all attributes necessary for a commercial cultivar (Hancock et al., 2008).

Because of this challenge, a germplasm bank with sufficient genetic variability is needed to enable that new cultivars with all the necessary traits to be obtained in the long term (Singh et al., 2018). The introduction of promising germplasm from other breeding programs is generally an effective alternative for increasing the genetic variability in question (Fagherazzi, 2017). Worldwide, several strawberry cultivars have already been obtained using parental from other breeding programs or even from other countries (Hancock et al., 2008).

This work aimed to evaluate advanced selections of strawberry regarding productive performance, fruit quality and resistance to anthracnose, powdery mildew and strawberry leaf spot, under conditions of South Plateau of Santa Catarina State. Through this work, we intend to increase the availability of promising strawberry genotypes for the characteristics studied, through a germplasm suitable for use in adaptability studies and breeding programs.

\section{Materials and methods}

The experiments were carried out in the municipality of Lages-SC, located under the coordinates ( $27^{\circ} 47^{\prime} \mathrm{S}$; $50^{\circ} 18^{\prime} \mathrm{W}$; elevation of 906 meters). The local climate is classified as humid subtropical mesotherm (Cfb), with annual mean temperature of $15.6^{\circ} \mathrm{C}$ and annual mean rainfall of $1,400 \mathrm{~mm}$ (Wrege et al., 2012).

The experimental design was randomized blocks, with three replications, and eleven plants per plot. The treatments consisted of eleven genotypes, being ten advanced selections - ITA 12,103-15; ITA 12,103-12; ITA 12,103-22; ITA 10,107-6; ITA 10,107-7; ITA 13,097-05; ITA 10,133-2; ITA 10,128-9; ITA 12,103-6 and ITA 10,107-12 - and the commercial cultivar 'San Andreas'.

The advanced selections in question are part of the third step of a genotype selection process. This 
process began in 2015, with the sowing and subsequent planting of 4,227 seedlings originating from 27 crosses. These crosses were carried out at the institution 'Consiglio per la Ricerca in Agricoltura e L'Analisi Dell'Economia Agraria - Centro di Ricerca Olivicoltura, Frutticoltura e Agrumicoltura '(CREA-OFA-FRF), in Forlì, Italy. The parents used in these crosses have good productivity and excellent fruit quality. The seeds were sent to Brazil, where in the 2015/2016 growing season, the plants originating from these seeds were subjected to a mass selection process in the field. In this step, 162 genotypes were chosen to be submitted to the subsequent evaluation step. In the 2016/2017 crop, these genotypes, now denominated advanced selections, were evaluated in plots consisting of five plants, still without repetition at this stage, due to the low production of stolons by plants selected in the previous cycle. Finally, ten selections were chosen to be propagated by stolons and later compared in a experiment with repetitions, together with the cultivar San Andreas, as described in this work.

The experiment was carried out using plug plants produced by rooting stolons in 72-cell expanded polystyrene trays filled with commercial substrate. The trays were kept in a greenhouse, receiving micro sprinkler irrigation, until the plants were rooted. The experiment was implemented on May 5,2017 . A soil cultivation system was used, in open field, in beds $1 \mathrm{~m}$ wide, $32.5 \mathrm{~m}$ long and about $15 \mathrm{~cm}$ high, raised with the aid of an implement coupled to a tractor. Plants were spaced $30 \times 30 \mathrm{~cm}$ between rows and plants, with three planting lines per bed.

A drip irrigation system was adopted, with three drip tapes per bed, arranged next to the planting lines, with spacing of $10 \mathrm{~cm}$ between drippers. Weeds management was performed through hoeing and hand removal. Phytosanitary control was carried out as needed, by spraying fungicides and insecticides registered for the crop. Soil correction and basic fertilization were made according the recommendations outlined in the Manual of Fertilization and Liming for the states of Rio Grande do Sul and Santa Catarina (SBCS, 2004). Complementary fertilization was performed supplying the nutrients via fertigation, using the following products: potassium sulfate $\left(\mathrm{K}_{2} \mathrm{SO}_{4}\right)$ (312.5 g 1000 plants $\left.^{-1}\right)$; magnesium sulfate $\left(\mathrm{MgSO}_{4}\right)$ (45.5 g 1000 plants ${ }^{-1}$ ); calcium nitrate $\left[\mathrm{Ca}\left(\mathrm{NO}_{3}\right)_{2}\right] \quad$ (99.2 g 1000 plants $\left.^{-1}\right)$; phosphate monohydrate (MAP) (387.4 g 1000 plants $^{-1}$ ) and P51 (liquid fertilizer containing $51 \%$ phosphorus) (73 mL 1000 plants $^{-1}$ ).

Fruits were harvested from September 21, 2017 to February 6, 2018, totaling 27 harvests. The fruits were picked up when they presented at least $80 \%$ of red skin. After each harvest, the fruits were counted and weighed, using a scale of three decimal places, divided into four categories, as follows: a) commercial - fruits with $10 \mathrm{~g}$ or more, without rotting or deformities; (b) small - fruits of less than $10 \mathrm{~g}$; c) rotten - fruits with mold and; d) misshapen - visible deformed fruits, which depreciate the commercial quality.
Once the harvesting period was finished, the following productive traits were assessed: a) total and commercial production $\left(\mathrm{g}_{\text {plant }}{ }^{-1}\right)$; b) yield $\left(\mathrm{t} \mathrm{ha}^{-1}\right)$, estimated by multiplying the production per plant by the plants density, which was 58,533.64 plant ha-1; c) number of total fruits per plant, and commercial fruits per plant; d) average fruit weight $(g)$ - commercial fruits were considered only, data were measured dividing the yield per plant by the number of fruits, in each plot; e) percentage of commercial, small, rotten, and misshapen fruits estimated by dividing the total fruits production in each category by the total yield, following the multiplication by 100 .

Fruit quality traits were evaluated three times during the season: September 28 and November 10, 2017; and January 10, 2018. The assessed traits were: a) skin color - performed with a colorimeter, measuring each berry in both sides on all fruits of each plot, obtaining the variables luminosity of the skin (L), saturation or chroma (c) and hue angle ( ${ }^{\circ}$ hue); b) firmness of pulp: measured with a digital bench penetrometer, equipped with a tip with $3.5 \mathrm{~mm}$ diameter, in a maximum of ten fruits per plot, on both sides of each fruit. The results were expressed in Newtons $(\mathrm{N})$; c) titratable acidity - titrated a $5 \mathrm{~mL}$ sample of pulp juice from all fruits of the plot in a $0.1 \mathrm{~N} \mathrm{NaOH}$ solution using bromothymol blue as acid-base indicator (Zenebon et al., 2008). The results were given in grams of citric acid per 100 grams of pulp (g $100 \mathrm{~g}^{-1}$ of citric acid); d) soluble solids content - performed with a digital refractometer, results in ${ }^{\circ}$ Brix; e) soluble solids / titratable acidity ratio - obtained by the ratio between the soluble solids content and the titratable acidity of each sample. In addition, the incidence and severity of three of the main diseases of the strawberry were evaluated: strawberry leaf spot (Mycosphaerella fragariae); powdery mildew (Sphaeroteca fuliginea); and anthracnose or 'black-flower' (Colletotrichum acutatum). For this purpose, six visual evaluations, in the field, were carried out between December 21, 2017 and February 23, 2018. For strawberry leaf spot and powdery mildew, the incidence was characterized by the percentage of leaves with symptoms, based in the total number of leaves in each plot. Severity, in turn, was calculated using a diagrammatic scale proposed by Mazaro et al. (2006), described as: 1 ) $-0.11 \%$ of the leaf area affected; 2 ) $-0.51 \%$ of the leaf area affected; 3) $-2.4 \%$ of leaf area destroyed; 4) - 10.2\%; and 5) $34.9 \%$ of damaged leaf area.

Regarding anthracnose, the incidence was defined as the number of structures with disease symptoms (flowers or fruits) divided by the total number of flowers or fruits present in the plot at the evaluation date, and then multiplied by 100 (\% of structures with symptons). Anthracnose severity, was evaluated using a scale of scores, in which the different organs affected in the plant define the severity degree, as follows: 1) anthracnose present in flowers; 2) necrotic lesions in the new fruits; 3) presence of mummified fruits; 4) Leaf disease symptoms, characterized by irregular spots. 
After completing the evaluations, severity of the diseases assessed was estimated by calculating the area under the disease progress curve (AUDPC), using the following equation:

$A U D P C=\Sigma[Y i+Y(i+1)] / 2[(X(i+1)-X i]$

wherein: $Y i$ is the disease severity at the time of evaluation; $Y(i+1)$ is the severity of the disease in the subsequent evaluation; $\mathrm{X} i$ is the plant age (days) at the evaluation date, and $X(i+1)$ is the plant age (days) in the subsequent evaluation.

The Shapiro-Wilk normality test and Levènne homogeneity of variances test were performed using software R (R Core Team, 2013). Data of average commercial fruit weight, titratable acidity and soluble solids / titratable acidity ratio were transformed by the formula $Y=x^{0.5}$. In turn, data of percentage of misshapen and rotten fruits, as well as incidence and severity of powdery mildew, were transformed by the formula $Y=(x+1)^{0,5}$. Data were submitted to analysis of variance, and the means were grouped by Scott-
Knott's test, at $5 \%$ of probability, using the software Sisvar (Ferreira, 2011).

\section{Results and discussion}

There was significant difference among genotypes evaluated for most of variables obtained, except for percentage of misshapen fruits (Table 3 ), hue angle of epidermis and pulp firmness (Table 4). The highest total and commercial productions were observed in the cultivar 'San Andreas', differing from all the evaluated selections (Table 1). This cultivar obtained a total production $69.6 \%$ superior than the general mean, which was $387.46 \mathrm{~g} \mathrm{plant}^{-1}$, and a commercial production $80.2 \%$ higher than the mean, which was $303.40 \mathrm{~g} \mathrm{plant}^{-1}$. Among the selections, higher values of total and commercial production were obtained for the genotypes ITA 10,107-6; ITA 13,097-5; ITA 10,133-2; and ITA 10,133-22, which did not differ from each other.

Table 1 - Productive traits of strawberry genotypes (Fragaria vs. ananassa Duch.). Lages, SC, 2019.

\begin{tabular}{lcccc}
\hline \multirow{2}{*}{ Genotype } & \multicolumn{2}{c}{$\begin{array}{c}\text { Production } \\
\left(\mathrm{g} \mathrm{plant}^{-1}\right)\end{array}$} & \multicolumn{2}{c}{ Yield } \\
\cline { 2 - 5 }$\left(\mathrm{t} \mathrm{ha}^{-1}\right)$
\end{tabular}

${ }^{*}$ Means followed by equal letters in the column belong to the same group by the Scott-Knott test at $5 \%$ of probability.

The genotypes 'San Andreas', ITA 12,103-22; ITA 10,133-2; ITA 10,107-12; ITA 10,107-7, and ITA 13,097-5 achieved the highest results for total number of fruits (Table 2). The cv. 'San Andreas' produced more commercial fruits in comparison to the other genotypes. Among the selections, the highest amount of commercial fruits was obtained for ITA 13,097-05 and ITA 10,133-2. Commercial fruits with higher average mass, were observed in
ITA 10,107-6; ITA 10,128-9; San Andreas; ITA 13,097-5; ITA 10,133-2; ITA 12,103-15; and ITA 12,103-6. In general, the most productive genotypes were also those with the highest number of fruits per plant, total and commercial. These results are in agreement with those obtained by Singh et al. (2018), for which both number of fruits and average fruit weight were positively correlated with the yield. 
Table 2 - Number of total and commercial fruits per plant; and average mass of total and commercial fruits of strawberry genotypes. Lages, SC, 2019.

\begin{tabular}{lccc}
\hline \multirow{2}{*}{ Genotype } & \multicolumn{2}{c}{$\begin{array}{c}\text { Number of fruits } \\
\left(\text { fruits plant }{ }^{-1} \text { ) }\right.\end{array}$} & $\begin{array}{c}\text { Average commercial fruit } \\
\text { weight } \\
\left(\text { fruit }^{-1}\right)^{* *}\end{array}$ \\
\cline { 2 - 3 } 'San Andreas' & Total & Commercial & $17.85 \mathrm{a}$ \\
ITA 12,103-15 & $47.17 \mathrm{a}^{*}$ & $30.81 \mathrm{a}$ & $15.98 \mathrm{a}$ \\
ITA 12,103-12 & $25.18 \mathrm{~b}$ & $15.16 \mathrm{c}$ & $12.46 \mathrm{~b}$ \\
ITA 12,103-22 & $22.47 \mathrm{~b}$ & $9.64 \mathrm{c}$ & $15.23 \mathrm{~b}$ \\
ITA 10,107-6 & $43.42 \mathrm{a}$ & $22.21 \mathrm{~b}$ & $19.34 \mathrm{a}$ \\
ITA 10,107-7 & $31.73 \mathrm{~b}$ & $19.27 \mathrm{c}$ & $13.97 \mathrm{~b}$ \\
ITA 13,097-5 & $35.83 \mathrm{a}$ & $15.59 \mathrm{c}$ & $16.63 \mathrm{a}$ \\
ITA 10,133-2 & $34.46 \mathrm{a}$ & $21.74 \mathrm{~b}$ & $16.37 \mathrm{a}$ \\
ITA 10,128-9 & $42.85 \mathrm{a}$ & $21.53 \mathrm{~b}$ & $18.44 \mathrm{a}$ \\
ITA 12,103-6 & $29.32 \mathrm{~b}$ & $16.60 \mathrm{c}$ & $15.95 \mathrm{a}$ \\
ITA 10,107-12 & $25.09 \mathrm{~b}$ & $14.52 \mathrm{c}$ & $13.96 \mathrm{~b}$ \\
\hline Mean & $37.90 \mathrm{a}$ & $17.32 \mathrm{c}$ & 16.01 \\
\hline CV $(\%)$ & 34.13 & 18.58 & 6.33 \\
\hline
\end{tabular}

* Means followed by equal letters in the column belong to the same group by the Scott-Knott test at $5 \%$ probability of error.

${ }^{* *}$ Data of average commercial fruit weight transformed by the formula $Y=x^{0.5}$.

The cultivar 'San Andreas' has greater productive potential than the cv. 'Albion', which is one of its genitors, as well as produces fruits of higher weight (Ruan et al., 2011). In the conditions of Lages, SC, this pattern was confirmed, with San Andreas being superior in production, average mass and fruit diameter, in comparison with Albion and Capitola cultivars, in soil and semi-hydroponic cultivation systems (Richter et al., 2018).

With exception of San Andreas, all genotypes evaluated obtained total yield values below the Brazilian average, which is $36.1 \mathrm{t} \mathrm{ha}^{-1}$, in 2015 (Fagherazzi et al., 2017b). The productions obtained were also lower than those obtained by Fagherazzi (2017), who evaluated 21 strawberry genotypes for adaptability in the municipality of Lages, SC, during three cycles of evaluation, obtaining a mean value of $615 \mathrm{~g} \mathrm{plant}^{-1}$. Richter (2018), evaluating four strawberry cultivars and two advanced selections, also in the municipality of Lages, SC, under protected environment, obtained average total productions of 695.7 and $627.9 \mathrm{~g} \mathrm{plant}^{-1}$, in the soil and semi-hidroponic cultivation systems, respectively.

In a general approach, the yields obtained with the advanced selections in the present study were very low. Possibly the conditions of temperature, relative humidity and water regime in the 2017/2018 season were not favorable to the productive performance of these selections. In addition, there is the fact that these selections were propagated through runners obtained from field. Thus, it is possible that, although special care was taken regarding to phytosanitary problems, some inoculum of diseases may have remained in the runners from one growing season to another, also leading to the an yield decrease.

Strawberry productivity is influenced by genetic, environmental, and the interaction of genetic $x$ environment factors. Among the environmental factors, those with the greatest influence are temperature, relative humidity, rainfall, and incidence of diseases and pests (Costa et al., 2015). As fruit yield in the strawberry is a quantitative trait and controlled by many genes, the influence of the environment on the productive performance of the cultivars is quite high (Hancock et al., 2008). Therefore, the recommendation of cultivars must to be regionalized, since a strawberry genotype with high performance in one region may not perform satisfactorily elsewhere (Mathey et al., 2017).

The genotypes that stood out with the largest percentages of production classified as commercial were ITA 13,097-5; San Andreas; ITA 10.107-6; ITA 10,128-9; ITA 12,103-15; ITA 12,103-6 and ITA 10,133-2, all forming a single group of means (Table 3 ). Higher percentages of the category small fruits were found for ITA 10,107-7; ITA 12,103-12; ITA 10,107-12; ITA 12,103-22 and ITA 10,133-2. The selection ITA 12,103-12 obtained the highest percentage of rotten fruits, differing from all other genotypes. 
Table 3 - Percentage of fruits in different categories, based on the total production of strawberry genotypes. Lages, SC, 2019.

\begin{tabular}{lcccc}
\hline \multirow{2}{*}{ Genotype } & \multicolumn{4}{c}{ Percentage of fruits in different categories } \\
\cline { 2 - 5 } & Commercial & Small & Misshapen $^{\star *}$ & Rotten $^{\star *}$ \\
\hline 'San Andreas' & $83.35 \mathrm{a}^{*}$ & $14.15 \mathrm{~b}$ & $1.31 \mathrm{a}$ & $1.19 \mathrm{~b}$ \\
ITA 12,103-15 & $79.42 \mathrm{a}$ & $19.23 \mathrm{~b}$ & $1.04 \mathrm{a}$ & $0.31 \mathrm{~b}$ \\
ITA 12,103-12 & $64.32 \mathrm{~b}$ & $28.05 \mathrm{a}$ & $1.06 \mathrm{a}$ & $6.57 \mathrm{a}$ \\
ITA 12,103-22 & $73.21 \mathrm{~b}$ & $25.09 \mathrm{a}$ & $0.59 \mathrm{a}$ & $1.10 \mathrm{~b}$ \\
ITA 10,107-6 & $83.12 \mathrm{a}$ & $14.09 \mathrm{~b}$ & $0.79 \mathrm{a}$ & $0.37 \mathrm{~b}$ \\
ITA 10,107-7 & $69.19 \mathrm{~b}$ & $30.07 \mathrm{a}$ & $0.11 \mathrm{a}$ & $0.63 \mathrm{~b}$ \\
ITA 13,097-5 & $86.14 \mathrm{a}$ & $11.11 \mathrm{~b}$ & $0.41 \mathrm{a}$ & $2.34 \mathrm{~b}$ \\
ITA 10,133-2 & $76.40 \mathrm{a}$ & $22.29 \mathrm{a}$ & $0.23 \mathrm{a}$ & $1.09 \mathrm{~b}$ \\
ITA 10,128-9 & $81.84 \mathrm{a}$ & $17.14 \mathrm{~b}$ & $0.34 \mathrm{a}$ & $0.68 \mathrm{~b}$ \\
ITA 12,103-6 & $78.50 \mathrm{a}$ & $20.47 \mathrm{~b}$ & $0.00 \mathrm{a}$ & $1.03 \mathrm{~b}$ \\
ITA 10,107-12 & $73.55 \mathrm{~b}$ & $25.98 \mathrm{a}$ & $0.00 \mathrm{a}$ & $0.47 \mathrm{~b}$ \\
\hline Mean & 77.19 & 20.85 & 0.53 & 1.43 \\
\hline CV (\%) & 6.33 & 20.35 & 21.22 & 22.47 \\
\hline
\end{tabular}

${ }^{*}$ Means followed by equal letters the column belong to the same group by the Scott-Knott test, at $5 \%$ probability of error.

${ }^{* \star}$ Data of percentage of misshapen and rotten fruits transformed by the formula $Y=(x+1)^{0.5}$.

The ability to produce greater share of marketable fruits is one of the most important characteristics aimed in a strawberry cultivar. This attribute contributes positively to the profitability of the investment, since it exerts influence on the fruits harvesting, selection, and packaging, which is very labor demanding. According to Ronque et al. (2013), the use of labor accounts for $30.53 \%$ of the total cost of strawberry production, and the stage of harvesting and packaging of the fruits corresponds to $19.25 \%$ of the total cost, considering the cultivation in the soil and in the open field, under conditions of the Metropolitan Region of Curitiba, PR.

The fruits classified as small (less than $10 \mathrm{~g}$ ) can be produced in many situations. For example, when the temperature, especially at night, is very high, there is an increase in the photorespiration rate, decreasing the liquid photosynthesis and the accumulation of carbohydrates, resulting in the formation of smaller fruits. However, the production of small fruits typically occurs in plants that are in the end of the harvesting period, and therefore, an end-of-cycle indicative (Vignolo, 2015). Deformed fruits, in turn, are usually the result of failures in pollination, and poorly shaped or positioned pistils above the anthers in the floral receptacle may also contribute to fruit formation in this class (Malagodi-Braga \& Kleinert, 2007). Be- sides, misshapen fruits can be also a genetic factor (Ariza et al., 2012). Rotten fruits are the result of infection by phytopathogens, and the most important in the region of the study is Botrytis cinerea, causal agent of gray mold, responsible for losses in the field and postharvest (Tanaka et al. 2005). According to the these authors, besides to Botrytis spp., other pathogens with potential to cause damage and losses from strawberry fruits are Colletotrichum acutatum, Rhizoctonia solani, Phytophthora cactorum and Rhizopus nigricans.

About the physical qualitative variables (skin color and pulp firmness), the genotypes ITA 10,107-7, ITA 13,097-5; and ITA 12,103-6 were defined as having a lighter epidermis (higher values of luminosity) and with a pure red coloration (higher chroma values) compared to the other genotypes (Table 4). The attributes related to coloring are among the main factors that influence consumers' acceptance of the product, since the purchase decision is often made based on the visual aspect (Carpenedo et al., 2016). The staining parameters in strawberry fruits are related to anthocyanin content, among them pelargonidin 3-glucoside and cyanidin-3-rutinoside (Cocco, 2014). The higher the concentration of these compounds, the lower the hue angle values of berry fruits, which means the red color is more intense. The content of anthocyanins in strawberries is variable according to the cultivar (Kovačević et al., 2015). 
Table 4 - Skin color and pulp firmness in fruits of strawberry genotypes. Lages, SC, 2019.

\begin{tabular}{|c|c|c|c|c|}
\hline \multirow{2}{*}{ Genotype } & \multicolumn{3}{|c|}{ Skin color } & \multirow{2}{*}{ Pulp firmness (N) } \\
\hline & Lightness & Chroma & ${ }^{\circ}$ hue & \\
\hline San Andreas & $34.13 b^{*}$ & $44.83 \mathrm{~b}$ & $30.76 \mathrm{a}$ & $5.25 \mathrm{a}$ \\
\hline ITA 12,103-15 & $35.11 \mathrm{~b}$ & $45.16 \mathrm{~b}$ & $29.28 \mathrm{a}$ & $5.01 \mathrm{a}$ \\
\hline ITA $12,103-12$ & $36.92 \mathrm{a}$ & $45.06 \mathrm{~b}$ & $29.35 \mathrm{a}$ & $5.64 \mathrm{a}$ \\
\hline ITA 12,103-22 & $32.78 \mathrm{~b}$ & $41.92 \mathrm{~b}$ & $28.81 \mathrm{a}$ & $5.38 \mathrm{a}$ \\
\hline ITA $10,107-6$ & $34.62 b$ & $42.56 \mathrm{~b}$ & $26.83 \mathrm{a}$ & $5.40 \mathrm{a}$ \\
\hline ITA $10,107-7$ & $40.25 \mathrm{a}$ & $49.82 \mathrm{a}$ & $34.59 \mathrm{a}$ & $5.31 \mathrm{a}$ \\
\hline ITA $13,097-5$ & $38.60 \mathrm{a}$ & $49.87 \mathrm{a}$ & $36.06 \mathrm{a}$ & $5.17 \mathrm{a}$ \\
\hline ITA 10,133-2 & $35.86 \mathrm{~b}$ & $45.67 \mathrm{~b}$ & $30.51 \mathrm{a}$ & $5.32 \mathrm{a}$ \\
\hline ITA $10,128-9$ & $36.61 \mathrm{a}$ & $45.27 \mathrm{~b}$ & $31.60 \mathrm{a}$ & $5.00 \mathrm{a}$ \\
\hline ITA 12,103-6 & $37.13 \mathrm{a}$ & $48.29 a$ & $31.98 \mathrm{a}$ & $5.14 \mathrm{a}$ \\
\hline ITA $10,107-12$ & $38.26 \mathrm{a}$ & $44.15 b$ & $32.37 \mathrm{a}$ & $5.40 \mathrm{a}$ \\
\hline Mean & 36.39 & 45.69 & 30.74 & 5.23 \\
\hline CV (\%) & 5.73 & 6.40 & 7.77 & 4.37 \\
\hline
\end{tabular}

${ }^{*}$ Means followed by equal letters the column belong to the same group by the Scott-Knott test at $5 \%$ probability of error.

Pulp firmness, in turn, is an attribute related to maintaining the integrity of cell walls. Throughout the maturation process, and during storage, ethylene stimulates the action of some enzymes, such as polygalacturonase, which degrade the calcium pectates, which constitute the 'cement' of the cell wall, reducing the integrity of the cell (Villarreal et al., 2009). In strawberry, this characteristic is highly variable between cultivars, and its inheritance is quantitative (Hancock et al., 2008). In the present work, a possible explanation for the absence of statistical difference between the evaluated genotypes for pulp firmness is the fact that, in the previous two stages of the selection, the firmness of the fruits was systematically evaluated in all the field inspections, being considered an eliminatory characteristic. Thus, genotypes that contained fruits of very soft consistency were eliminated from the selection process, even if they were promising for the other characteristics. The rigor in the application of this criterion may have contributed to the low genetic variability for this character within the selected population.

Regarding the chemical characteristics of the fruits (Table 5), higher values of titratable acidity were observed in the following genotypes: ITA 12,103-22; San Andreas; ITA 10,128-9, and ITA 10.107-7. Higher soluble solids contents were found for ITA 10,128-9; ITA 10.133-2; ITA 13.097-5; ITA 10.107-7, and ITA 10.107-12. For soluble solids / titratable acidity ratio, nine of the eleven genotypes formed a single group of averages, with values higher than the cultivar San Andreas and the selection ITA 12,103-22, which obtained the lowest results.

The titratable acidity in the strawberry is characterized by the content of organic acids, notably citric and malic acids. As the maturation process progresses, the content of these compounds tends to decrease as the concentration of soluble solids increases. The main soluble sugars present in the strawberry pulp, in turn, are glucose, fructose and sucrose. In the strawberry, the titratable acidity and the soluble solids content are quantitative characteristics, with varying levels of additive and dominance control (Hancock et al., 2008). Genotype and climatic conditions are the two main factors that affect the expression of these characteristics. Among the climatic factors, water availability is what exerts the greatest influence. In such a way, excessive rains or irrigation reduces the concentration of sugars in the fruits, making them more insipid (Mackenzie et al., 2011).

The fruits of a particular strawberry cultivar are considered adequate for in natura consumption when they have values for soluble solids content and soluble solids / titratable acidity ratio of, at least, $7.0^{\circ}$ Brix and 8.75, respectively (Kader, 2002, cited by Souza et al., 2017). Regarding these parameters, with exception of the selections ITA 12,103-12 and ITA 12,103-15, which obtained soluble solids content values bellow 7.0, all genotypes studied showed qualitative characters that make them apropriate for commercialization as fresh fruit. 
Table 5 - Titratable acidity, soluble solids content and soluble solids / titratable acidity ratio of strawberry genotypes. Lages, SC, 2019.

\begin{tabular}{lccc}
\hline Genotype & $\begin{array}{c}\text { Titratable acidity } \\
\left(\mathrm{g} 100 \mathrm{~g}^{-1} \text { of citric acid }\right)^{* *}\end{array}$ & $\begin{array}{c}\text { Soluble solids content } \\
\left({ }^{\circ} \text { Brix }\right)\end{array}$ & $\begin{array}{c}\text { Soluble solids / titratable } \\
\text { acidity ratio }(\mathrm{SS} / \mathrm{TA})^{* *}\end{array}$ \\
\hline San Andreas & $0.71 \mathrm{a}^{*}$ & $7.77 \mathrm{~b}$ & $11.08 \mathrm{~b}$ \\
ITA 12,103-15 & $0.44 \mathrm{~b}$ & $6.52 \mathrm{~b}$ & $14.79 \mathrm{a}$ \\
ITA 12,103-12 & $0.43 \mathrm{~b}$ & $6.53 \mathrm{~b}$ & $15.63 \mathrm{a}$ \\
ITA 12,103-22 & $0.74 \mathrm{a}$ & $7.73 \mathrm{~b}$ & $10.52 \mathrm{~b}$ \\
ITA 10,107-6 & $0.49 \mathrm{~b}$ & $7.98 \mathrm{~b}$ & $16.40 \mathrm{a}$ \\
ITA 10,107-7 & $0.60 \mathrm{a}$ & $8.77 \mathrm{a}$ & $14.70 \mathrm{a}$ \\
ITA 13,097-5 & $0.50 \mathrm{~b}$ & $9.07 \mathrm{a}$ & $18.60 \mathrm{a}$ \\
ITA 10,133-2 & $0.53 \mathrm{~b}$ & $9.35 \mathrm{a}$ & $17.77 \mathrm{a}$ \\
ITA 10,128-9 & $0.68 \mathrm{a}$ & $9.53 \mathrm{a}$ & $14.33 \mathrm{a}$ \\
ITA 12,103-6 & $0.56 \mathrm{~b}$ & $8.03 \mathrm{~b}$ & $14.51 \mathrm{a}$ \\
ITA 10,107-12 & $0.54 \mathrm{~b}$ & $8.65 \mathrm{a}$ & $15.95 \mathrm{a}$ \\
\hline Mean & 0.57 & 8.17 & 14.93 \\
\hline CV $(\%)$ & 8.49 & 13.01 & 6.07 \\
\hline
\end{tabular}

${ }^{*}$ Means followed by equal letters the column belong to the same group by the Scott-Knott test at $5 \%$ probability of error.

** Data of titratable acidity and soluble solids / titratable acidity ratio transformed by the formula $\mathrm{Y}=\mathrm{x}^{0.5}$.

In the present study, it is possible to assume that the selections ITA 10,128-9; ITA 10,133-2; ITA 13,097-5; ITA 10,107-7, and ITA 10,107-12 present good potential for selection based on the qualitative characteristics of the fruits. These genotypes could serve as an auxiliary germplasm for breeding programs aiming improvements in fruit quality. High soluble solids contents, as well as high ratios of soluble solids and titratable acidity, are positively correlated with consumer acceptance of the product. Higher acidity values, on the other hand, reduce fruit acceptance (Resende et al., 2008). Thus, the study of sensorial attributes of fruits is essential in the process of selection and recommendation of new cultivars, since the acceptance by the consumers defines if these cultivars will obtain market for the production flow.

In relation to the incidence of the diseases evaluated, higher incidences of leaf strawberry spot were observed in ITA 10,128-9; ITA 10,133-2, and ITA 12,103-6 (Table 6). The genotypes with the lowest incidence of leaf spot, on the other hand, were ITA 12,103-22; ITA 10,107-7; ITA 10,107-12 and ITA 13,097-5. For powdery mildew, in turn, the highest incidence was observed in the selection ITA 10,128-9, while the lowest incidence ocurred in ITA 10,107-7 and ITA 10,133-2. Regarding the incidence of anthracnose, the highest value was obtained with selection ITA 12,103-22 and the lowest with ITA 10,133-2.

Regarding severity of the diseases evaluated, for micosferela stain, the selection ITA 10,133-2 was the most susceptible, differing from all other genotypes; while the selections ITA 10,107-7; ITA 10,107-12;
ITA 12,103-22; ITA 12,103-15 and ITA 13,097-5 were the least susceptible to the micosferela stain, forming a single group of means (Table 7). With respect to powdery mildew, genotype ITA 12,103-22 was the most susceptible. On the other hand, the genotypes ITA 12,103-12; ITA 10,107-7; ITA 10,107-12; ITA 10,133-2 and ITA 13,097-5 presented the lowest susceptibility. The genotype ITA 13,097-5 presented the highest mean severity for anthracnose, while the lowest values were obtained with ITA 12,103-15; ITA 10,107-12 and ITA 10,133-2.

The micosferela stain severity averages found in this study were, in general, smaller than the values found by Mazaro et al. (2012), which used fungicides and alternative products in the treatment of leaf spot in plants of the Aromas cultivar. These averages were also lower than those obtained by Mazaro et al. (2013), which evaluated the effectiveness of treatments with products authorized for organic cultivation in the control of strawberry leaf spot in plants of the Camarosa cultivar, and very smaller than the values found by Heling et al. (2015). However, the means found in the present work were very higher than those obtained by Nesi et al. (2013), which evaluated the incidence and severity of this disease in eight cultivars.

According to Brugnara \& Colli (2014), the incidence of leaf spot on the strawberry depends on factors such as cultivar, use of plastic cover on the site and cultural practices, such as the removal of older leaves. The influence of the cultivar is one of the most decisive in this sense, since the resistance and / or susceptibility to leaf spot is, to a large extent, defined by genetics. Still according to the same authors, the 
use of plastic cover or cultivation in protected environment, in turn, prevents leaf wetting, which is an indispensable condition for infection by the pathogen. In many municipalities of Santa Catarina, from August to January, period of highest strawberry production in this State (Rojas Molina, 2016), monthly rainfall is over 100 millimeters each month, and the relative humidity is high (Wrege et al., 2012). This fact reinforces the importance of the development of new strawberry cultivars resistant to leaf spot, in addition to practices such as use of protected cultivation, as part of management to improve crop health and minimize fungicide use.

Table 6 - Incidence of strawberry leaf spot, powdery mildew and anthracnose in advanced selections of strawberry. Lages, SC, 2018.

\begin{tabular}{lccc}
\hline Genotype & $\begin{array}{c}\text { Strawberry leaf spot } \\
\text { (\% of leaflets attacked) }\end{array}$ & $\begin{array}{c}\text { Powdery mildew } \\
\text { (\% of leaflets attacked) }{ }^{* *}\end{array}$ & $\begin{array}{c}\text { Anthracnose } \\
\text { (\% of flowers and fruits } \\
\text { attacked })\end{array}$ \\
\hline ITA 12,103-15 & $16.70 \mathrm{~b}^{*}$ & $3.09 \mathrm{c}$ & $9.02 \mathrm{~d}$ \\
ITA 12,103-12 & $16.52 \mathrm{~b}$ & $0.00 \mathrm{e}$ & $34.45 \mathrm{~b}$ \\
ITA 12,103-22 & $8.30 \mathrm{c}$ & $5.30 \mathrm{~b}$ & $51.23 \mathrm{a}$ \\
ITA 10,107-6 & $15.71 \mathrm{~b}$ & $2.93 \mathrm{c}$ & $17.22 \mathrm{c}$ \\
ITA 10,107-7 & $8.76 \mathrm{c}$ & $0.29 \mathrm{e}$ & $21.81 \mathrm{c}$ \\
ITA 13,097-5 & $11.16 \mathrm{c}$ & $1.34 \mathrm{~d}$ & $36.85 \mathrm{~b}$ \\
ITA 10,133-2 & $21.81 \mathrm{a}$ & $0.73 \mathrm{e}$ & $2.87 \mathrm{e}$ \\
ITA 10,128-9 & $22.89 \mathrm{a}$ & $7.69 \mathrm{a}$ & $19.93 \mathrm{c}$ \\
ITA 12,103-6 & $20.26 \mathrm{a}$ & $2.11 \mathrm{~d}$ & $18.65 \mathrm{c}$ \\
ITA 10,107-12 & $10.99 \mathrm{c}$ & $1.09 \mathrm{~d}$ & $22.34 \mathrm{c}$ \\
\hline Mean & 15.31 & 2.46 & 23.44 \\
\hline CV $(\%)$ & 11.54 & 11.04 & 12.27 \\
\hline
\end{tabular}

${ }^{*}$ Means followed by equal letters the column belong to the same group by the Scott-Knott test at $5 \%$ probability of error.

** Data of powdery mildew incidence transformed by the formula $Y=(x+1)^{0.5}$.

Table 7 - Area under the disease progress curve (AUDPC), for micosferella stain, powdery mildew and anthracnose severity, in advanced selections of strawberry. Lages, SC, 2018.

\begin{tabular}{|c|c|c|c|}
\hline Genotype & $\begin{array}{c}\text { Strawberry leaf spot } \\
\text { (AUDPC) }\end{array}$ & $\begin{array}{c}\text { Powdery mildew** } \\
\text { (AUDPC) }\end{array}$ & $\begin{array}{l}\text { Anthracnose } \\
\text { (AUDPC) }\end{array}$ \\
\hline ITA $12,103-15$ & $10.45 f^{*}$ & $2.97 \mathrm{c}$ & $17.05 d$ \\
\hline ITA $12,103-12$ & $38.30 \mathrm{c}$ & $0.00 \mathrm{~d}$ & $73.50 \mathrm{~b}$ \\
\hline ITA 12,103-22 & $5.46 \mathrm{f}$ & $42.26 \mathrm{a}$ & $71.13 \mathrm{~b}$ \\
\hline ITA $10,107-6$ & $17.86 \mathrm{e}$ & $4.36 \mathrm{c}$ & $57.56 \mathrm{c}$ \\
\hline ITA $10,107-7$ & $4.98 \mathrm{f}$ & $0.34 \mathrm{~d}$ & $71.33 \mathrm{~b}$ \\
\hline ITA $13,097-5$ & $10.91 \mathrm{f}$ & $0.74 \mathrm{~d}$ & $84.75 \mathrm{a}$ \\
\hline ITA $10,133-2$ & $69.84 \mathrm{a}$ & $0.50 \mathrm{~d}$ & $42.85 d$ \\
\hline ITA $10,128-9$ & $46.94 \mathrm{~b}$ & $22.76 \mathrm{~b}$ & $57.56 \mathrm{c}$ \\
\hline ITA $12,103-6$ & $24.58 d$ & $5.51 \mathrm{c}$ & $63.00 \mathrm{c}$ \\
\hline ITA $10,107-12$ & $5.45 \mathrm{f}$ & $0.39 d$ & $37.50 \mathrm{~d}$ \\
\hline Mean & 23.48 & 7.98 & 57.62 \\
\hline CV (\%) & 15.09 & 12.61 & 11.32 \\
\hline
\end{tabular}


With respect to resistance / susceptibility to powdery mildew, the results obtained for AUDPC are similar to those found by Carisse et al. (2013), who obtained values ranging from 10 to 30 for this variable, in fields of commercial production of Quebec Province, Canada. These authors observed that losses in productivity of the order of $5 \%$ occurred from the moment the percentage of infected leaf area reached $17 \%$. In the present study, two genotypes were among the most susceptible within the studied population: ITA 12,103-22 and ITA 10,128-9. According to Cockerton et al. (2018) the inheritance of resistance to strawberry powdery mildew is quantitative and, in major part, aditive, being the expression of this characteristic a result of the sum of small individual contributions by several genes.

Under current conditions, where strawberry production has gradually migrated to the cultivation suspended in protected environment, cultivars resistant to powdery mildew take on even greater importance. This is because, in a protected environment, conditions favoring this disease are common, such as absence of leaf wetness and temperatures between $15^{\circ} \mathrm{C}$ and $30{ }^{\circ} \mathrm{C}$ (Tanaka et al. 2005).

Resistance to anthracnose, in turn, is also an important objective to be sought in the production of new strawberry cultivars, due to the wide geographic distribution of the causal agent, and the potential for losses and damages that it presents in the fields of production commercial, which can reach more than $80 \%$ in productivity reduction (Mertely et al. 2010). In this sense, the ideal is that this disease be managed in a preventive way, through practices such as balancing nitrogen fertilization, avoiding leaf wetting (Tanaka et al. 2005) and using healthy seedlings in the implantation of the crop, can be brought from nurseries and manifest in the field of commercial production (Daugovish et al., 2012).

The incidence and severity averages for the same disease were all positively correlated with each other (Table 8). The incidence of anthracnose, in turn, was inversely correlated with the incidence and severity of leaf spot. Studies that correlate anthracnose and leaf spot on the progress of the disease or the damage caused are scarce. It is possible that the cause of the inverse correlation found in the present study is mainly genetic, since the environmental conditions favorable to the occurrence of these two diseases are similar, which are characterized by constant humidity and mild to slightly elevated temperatures (Tanaka et al. 2005).

Table 8 - Estimates of Pearson correlations among incidence and severity of strawberry leaf spot, powdery mildew and anthracnose in advanced selections of strawberry. Lages, SC, 2018.

\begin{tabular}{lcccccc}
\hline & LSINC & LSSEV & PMINC & PMSEV & ANINC & ANSEV \\
\hline LSINC & - & $0.80^{* *}$ & 0.19 & 0.16 & $-0.60^{* *}$ & -0.27 \\
LSSEV & & - & 0.04 & 0.10 & $-0.45^{*}$ & -0.08 \\
PMINC & & & - & $0.77^{* *}$ & 0.13 & -0.08 \\
PMSEV & & & & - & $0.55^{* *}$ & 0.18 \\
ANINC & & & & & - & $0.67^{* *}$ \\
ANSEV & & & & & & - \\
\hline
\end{tabular}

* Significant correlation at $5 \%$ probability of error. ${ }^{* *}$ Significant correlation at $1 \%$ probability of error.

LSINC = Strawberry leaf spot incidence (\% of leaflets attacked). LSSEV = Strawberry leaf spot severity (AUDPC). PMINC = Powdery mildew incidence (\% of leaflets attacked). PMSEV = Powdery mildew severity (AUDPC). ANINC = Anthracnose incidence (\% of flowers and fruits attacked). ANSEV = Anthracnose severity (AUDPC).

In a general approach, the selections ITA 12,103-15 and ITA 10,107-12 are in the groups with lowest mean of incidence and severity of the three diseases evaluated simultaneously (Tables 6 and 7). Thus, these genotypes presented the best results regarding the resistance to the main strawberry disease, among the genotypes studied. In this sense, these selections could be good parents in breeding programs aimed at promoting disease resistance.

\section{Conclusions}

The cultivar San Andreas has higher yield and number of commercial fruits among the genotypes evaluated in this study.

The selections ITA 10,133-2; ITA 10,128-9; ITA 13,097-5; ITA $10,107-7$ and ITA 10,107-12 have good fruit quality, expressed as high averages for soluble solids content and soluble solids / titratable acidity ratio.

The genotypes ITA 12,103-15 and ITA 10,107-12 present the highest simultaneous resistance against strawberry leaf spot, powdery mildew and anthracnose, among genotypes studied.

The advanced selections must be evaluated for more years and locations to verify if they will can or not be utilized in a commercial scale.

\section{Acknowledgments}

The first author thank to the Coordenação de Aperfeiçoamento de Pessoal de Nível Superior (CAPES) for the scholarship award. 


\section{References}

Antunes LEC, Peres NA (2013) Strawberry production in Brazil and South America. International Journal of Fruit Science, 13(1-2): 156-161.

Antunes LEC, Ristow NC, Krolow ACR, Carpenedo S, Reisser Júnior C (2010) Yield and quality of strawberry cultivars. Horticultura Brasileira 28(2): 222-226.

Ariza MT, Soria C, Medina-Mínguez JJ, Martínez-Ferri E (2012) Incidence of Misshapen in Strawberry Plants Grown under Tunnels is Affected by Cultivar, Planting Date, Pollination, and Low Temperatures. HortScience 47(11): 1569-1573.

Brugnara EC, Colli MP (2014) Leaf spot and leaflet removal in day-neutral strawberry cultivars under different cultivation conditions, in organic management. IDESIA (Chile) 32(1): 89-92.

Carisse O, Morissette-Thomas V, Van der Heyden H (2013) Lagged association between powdery mildew leaf severity, airborne inoculum, weather, and crop losses in strawberry. Phytopathology 103(8): 811-821.

Carpenedo S, Antunes LEC, Treptow RO (2016) Caracterização sensorial de morangos cultivados na região de Pelotas. Horticultura Brasileira 34(4): 565570.

Cocco C (2014) Produção e qualidade de mudas de morangueiro no Brasil e na Itália. Universidade Federal de Pelotas (Tese de doutorado em Fruticultura de Clima Temperado).

Cockerton HM, Vickerstaff RJ, Karlström A, Wilson F, Sobczyk M, He JQ, Sargent DJ, Passey AJ, Mcleary KJ, Pakozdi K, Lumbreras-Martínez M, Antanaviciute L, Simpson DW, Harrison N (2018) Identification of powdery mildew resistance QTL in strawberry (Fragaria $x$ ananassa). Theoretical and Applied Genetics 131(9): 1995-2007.

Costa AF, Leal NR, Ventura JA, Gonçalves LSA, Amaral Júnior ATD, Costa H (2015) Adaptability and stability of strawberry cultivars using a mixed model. Acta Scientiarum. Agronomy 37(4): 435-440.

Costa AF, Teodoro PE, Bhering LL, Leal NR, Tardin FD, Daher RF (2016) Biplot analysis of strawberry genotypes recommended for the State of Espírito Santo. Genetics and Molecular Research 15(3): 01-09.

Daugovish O, Bolda M, Kaur S, Mochizuki MJ, Marcum D, Epstein L (2012) Drip irrigation in California strawberry nurseries to reduce the incidence of Colletotrichum acutatum in fruit production. HortScience 47(3): 368-373.
Fagherazzi AF, Bortolini AJ, Zanin DS, Bisol L, Santos AM, Grimaldi F, Kretzschmar AA, Baruzzi G, Faedi W, Lucchi $P$, Rufato L (2017a) New strawberry cultivars and breeding activities in Brazil. Acta Horticulturae 1156: 167-170.

Fagherazzi AF, Grimaldi F, Kretzschmar AA, Molina AR, Gonçalves MA, Antunes LEC, Baruzzi G, Rufato L (2017b) Strawberry production progress in Brazil. Acta Horticulturae 1156: 937-940.

Fagherazzi AF (2017) Adaptabilidade de novas cultivares e seleções de morangueiro para o Planalto Sul Catarinense. Universidade do Estado de Santa Catarina (Tese de doutorado em Produção Vegetal).

Ferreira DF (2011) Sisvar: a computer statistical analysis system. Ciência e Agrotecnologia 35(6): 10391042.

Galvão AG (2014) Hibridação de morangueiro e seleção de clones com potencial para cultivo no sul de Minas Gerais. Universidade Federal de Lavras (Tese de doutorado em Fitotecnia).

Hancock JF, Sjulin TM, Lobos GA (2008) Strawberries. In: Hancock JF (ed) Temperate fruit crop breeding, Springer, p.393-437.

Heide OM, Stavang JA, Sønsteby A (2013) Physiology and genetics of flowering in cultivated and wild strawberries - a review. The Journal of Horticultural Science and Biotechnology 88(1): 1-18.

Heling AL, Kuhn OJ, Stangarlin JR (2015) Controle biológico de Mycosphaerella fragariae na cultura do morangueiro. Scientia Agraria Paranaensis 14(4): 221 228.

Kader A (2002) Standardization and Inspection of Fresh Fruits and Vegetables. In: Kader A (ed) Postharvest Technology of Horticultural Crops. 3. ed. University of California. p.287-300.

Kovačević DB, Putnik P, Dragović-Uzelac V, Vahčić N, Babojelić MS, Levaj B (2015) Influences of organically and conventionally grown strawberry cultivars on anthocyanins content and color in purees and lowsugar jams. Food chemistry 181: 94-100.

MacKenzie SJ, Chandler CK, Hasing T, Whitaker VM (2011) The role of temperature in the late-season decline in soluble solids content of strawberry fruit in a subtropical production system. HortScience 46(11): 1562-1566.

Malagodi-Braga KS, Kleinert ADMP (2007) Como o comportamento das abelhas na flor do morangueiro (Fragaria ananassa Duchesne) influencia a formação dos frutos?. Bioscience Journal 23(1): 76-81. 
Mathey MM, Mookerjee S, Mahoney LL, Gündüz K, Rosyara U, Hancock JF, Stewart PJ, Whitaker VM, Bassil NV, Davis TM, Finn CE (2017) Genotype by environment interactions and combining hability for strawberry families grown in diverse environments. Euphytica 213(5): 112.

Mazaro SM, Gouvea A, May De Mio LL, Deschamps C, Biasi LA, Citadin I (2006) Escala diagramática para avaliação da severidade da mancha-de-micosferela em morangueiro. Ciência Rural 36(2): 648-652.

Mazaro SM, Caprini Mangnabosco M, Citadin I, Paulus D, de Gouvea A (2013) Produção e qualidade de morangueiro sob diferentes concentrações de calda bordalesa, sulfocálcica e biofertilizante supermagro. Semina: Ciências Agrárias 1(34): 3285-3294.

Mazaro SM, Deschamps C, de Gouvea A, Citadin I, Wagner Junior, A (2012) Indução de resistência a doenças foliares e de flores em morangueiro por quitosana e acibenzolar-s-metil. Current Agricultural Science and Technology 18(2): 143-150.

Mertely JC, Seijo TE, Peres NA (2010) Effect of pre and post-plant fungicide and fertilizer treatments on infection by Colletotrichum acutatum, plant survival, and yield of annual strawberry in Florida. Plant Health Progress. https://doi. org/10.1094/PHP-2010-0125-01RS Google Scholar.

Mishra PK, Ram RB, Kumar N (2015) Genetic variability, heritability, and genetic advance in strawberry (Fragaria $x$ ananassa Duch.). Turkish Journal of Agriculture and Forestry 39(3): 451-458.

Nesi CN, Kuhn TMA, Araujo ES, Mógor ÁF, May De Mio LL (2013) Avaliação de extrato de algas no progresso temporal da mancha de mycosphaerella em cultivares de morangueiro. Revista Ceres 60(1): 38-42.

Oliveira ABC, Bonow S (2012) Novos desafios para o melhoramento genético da cultura do morangueiro no Brasil. Informe Agropecuário 33(268): 21-26.

R Core Team (2013) R: A language and environment for statistical computing. Disponível em: <http://www.R-project.org/> (Acesso em 02 jun 2018).

Resende JTV, Camargo LK, Argandoña EJ, Marchese A, Camargo CK (2008) Sensory analysis and chemical characterization of strawberry fruits. Horticultura Brasileira 26(3): 371-374.

Richter AF, Fagherazzi AF, Zanin DS, Camargo SS, Arruda AL, Kretzschmar AA, Rufato L, Silva PS (2018) Produtividade e qualidade do morango sob cultivo de solo e semi-hidropônico. Revista Científica Rural 20(1): 193-203.

Richter AF (2018) Produção e qualidade de genótipos de morangueiro em diferentes sistemas de cultivo. Universidade do Estado de Santa Catarina (Dissertação de Mestrado em Produção Vegetal).
Rojas Molina AM (2016) A cultura do morangueiro (Fragaria $x$ ananassa Duch.) no estado de Santa Catarina: sistemas de produção e riscos climáticos. Universidade Federal de Santa Catarina (Dissertação de Mestrado em Recursos Genéticos Vegetais).

Ronque ERV, Ventura MU, Soares Júnior D, Macedo RB, Campos BRS (2013) Viabilidade da cultura do morangueiro no Paraná-BR. Revista Brasileira de Fruticultura 35(4): 1032-1041.

Ruan J, Yeoung YR, Larson KD (2011) Influence of cultivar, planting date, and planting material on yield of day-neutral strawberry cultivars in highland areas of Korea. Horticulture, Environment, and Biotechnology 52(6): 567-575.

SBCS - Sociedade Brasileira de Ciência do Solo (2004) Manual de adubação e calagem para os estados de Rio Grande do Sul e Santa Catarina. Núcleo Regional Sul: Comissão de Química e Fertilidade do Solo - RS/SC, 400 p.

Singh G, Kachwaya DS, Kumar R, Vikas G \& Singh L (2018) Genetic variability and association analysis in strawberry (Fragaria $x$ ananassa Duch). Electronic Journal of Plant Breeding, 9(1): 169-182.

Souza DC, Vieira SD, Resende LV, Galvão AG, Ferraz AKL, Resende JTV \& Elias EHS (2017) Propriedades físico-químicas em frutos de híbridos experimentais de morangueiro. Agrotrópica, 29(1): 85-96.

Tanaka MAS, Betti JA, Kimati H (2005) Doenças do morangueiro (Fragaria $x$ ananassa). In: Kimati $\mathrm{H}$, Amorim L, Bergamin Filho A, Camargo LEA, Rezende JAM (ed.). Manual de Fitopatologia: Doenças das plantas cultivadas. 4 ed. Agronômica Ceres, p.489-499.

Tazzo IF, Fagherazzi AF, Lerin S, Kretzschmar AA, Rufato $L$ (2015) Exigência térmica de duas seleções e quatro cultivares de morangueiro cultivado no planalto catarinense. Revista Brasileira de Fruticultura 37(3): 550-558.

Vignolo GK (2015) Produção e qualidade de morangos durante dois ciclos consecutivos em função da data de poda, tipo de filme do túnel baixo e cor do mulching plástico. Universidade Federal de Pelotas (Tese de Doutorado em Fruticultura de Clima Temperado).

Villarreal NM, Martínez GA, Civello PM (2009) Influence of plant growth regulators on polygalacturonase expression in strawberry fruit. Plant Science 176(6): 749-757.

Wrege MS, Steinmetz $S$, Reisser Júnior $C$, Almeida IR (2012) Atlas climático da região sul do Brasil: estados do Paraná, Santa Catarina e Rio Grande do Sul. Embrapa Clima Temperado; Embrapa Florestas. 334p.

Zenebon O, Pascuet NS, Tiglea P (coord.) (2008) Métodos físico-químicos para análise de alimentos. 4. ed. Instituto Adolfo Lutz. 1020 p. 